\title{
Workforce exposure to rockfalls in underground mines
}

\author{
M.L. Owen Owen Risk Engineering, Australia
}

\begin{abstract}
Risk assessment and workplace safety is a hot topic in the mining industry. Recent years of media interest have seen mine safety being dissected in the public domain. The application of risk analysis techniques to the management of personnel safety is being promoted by both industry and regulators but, particularly for geotechnical hazards, often there are inadequate databases for a meaningful quantitative calculation of risk.

This paper presents an empirical model for quantifying the exposure of personnel to geotechnical hazards in underground mines. The exposure model parameters relate to temporal, spatial and vulnerability probabilities as developed by Owen (2004), using both empirical data and mechanistic principles.

Ultimately, the model gives the relative level of exposure of mine personnel to rockfalls/rockbursts before converting the exposure rating to a probability of fatality, correlated with mining accident statistics. This allows the effectiveness of various risk reduction strategies to be more accurately assessed so efforts can be prioritised, bringing the mining industry more in line with risk assessment and reporting practices within the petrochemical sector.
\end{abstract}

\section{Introduction}

Risk assessment in the mining industry is currently a topic of great interest, with analyses of risks due to various physical hazards including chemical, electrical, mechanical and geotechnical sources. In Western Australia between 1987-1997, the annual fatality incidence for underground mining was high, averaging 1.3 in 1000 employees. Rockfalls/rockbursts accounted for over half of these deaths (MOSHAB, 1997).

Over the next decade, 1998-2008, records from the Minerals Council of Australia (2007) show a halving of the fatality rate in Western Australian underground metalliferous mines: 38 deaths over 10 years. Of these, the fatality incidence due to rockfalls has fallen substantially to an average of 0.07 in 1000 employees; excluding a mine fill collapse which caused three fatalities. The order of magnitude decrease may be attributed to Western Australia mines improving ground control measures and implementing various recommendations from the Prevention of Mining Fatalities Taskforce (MOSHAB, 1997). However, this fatality rate appears fairly static over time and it is suggested that another definitive reduction will be difficult to achieve without increased efforts to quantify the uncertainties that remain in the complex area of geotechnical risk in mining.

Risk calculations require information about the source of the hazard, the personnel or assets exposed to the hazard (the "elements at risk"), and the effects on these vulnerable elements if the hazard actually occurs the potential consequences. To date, little information has been available on the exposure of mining personnel and equipment to underground hazards other than occupational safety studies on chemicals, heat, dust, etc. This paper concentrates on underground geotechnical risks and presents a data collection and rating system for the exposure of the underground workforce to rockfalls and rockbursts. The methodology considers exposure times, personnel protection levels and hazard proximities to give exposure ratings for the major underground mining activities and hence rate different locations within a mine.

The model profiles typical work activities in an underground mine, considering:

- The number of personnel in a work area.

- The amount of time that the personnel are in the area.

- The level of protection provided to personnel.

- Any higher risk activities that occur concurrently. 
Ultimately, the model gives the relative level of exposure to rockfalls/rockbursts, dependent on the activity in the workplace. The model was calibrated with data from Big Bell, Brunswick Mining in Canada, BHP Billiton's Cannington mine and WMC's Leinster Nickel Operation Perseverance Mine. Further details and case studies can be found in Owen (2004).

\section{Workforce exposure methodology}

From the literature reviewed (Owen, 2004) it was concluded that the most analogous situation to underground mining exposure to geotechnical hazards was in the civil engineering sector - for the assessment of the exposure of structures and roadways to landslide hazards. The landslide guidelines (AGS, 2000) defined a quantitative risk calculation, based on work by Bunce et al. (1997), as follows:

$$
\mathrm{R}_{(\mathrm{DI})}=\mathrm{P}_{(\mathrm{H})} \times \mathrm{P}_{(\mathrm{S}: \mathrm{H})} \times \mathrm{P}_{(\mathrm{T}: \mathrm{S})} \times \mathrm{V}_{(\mathrm{D}: \mathrm{T})}
$$

where:

$$
\begin{array}{ll}
\mathrm{R}_{\text {(DI) }} & \text { = risk (annual probability of loss of life). } \\
\mathrm{P}_{(\mathrm{H})} & \text { = annual probability of the hazardous event (i.e. the landslide, rockfall, etc.). } \\
\mathrm{P}_{(\mathrm{S}: \mathrm{H})} & \text { = probability of spatial impact (e.g. of a building, vehicle, etc.) by the hazard (the landslide). } \\
\mathrm{P}_{(\mathrm{T}: \mathrm{S})} & \text { = temporal probability (e.g. of building occupation) given the spatial impact. } \\
\mathrm{V}_{\text {(D:T) }} & \text { = vulnerability of the individual (probability of loss of life given the impact). }
\end{array}
$$

The exposure quantification presented is consistent with the above breakdown of the risk components. It was decided that the exposure model for the rockfall/rockburst context should produce a result representing the relative likelihood of severe consequence to personnel - i.e. serious injury or fatality. A linear model structure, with parameters representing independent probabilities that contribute to the likelihood of severe consequence resulting from a rockfall/rockburst, was therefore judged appropriate.

The mine excavations were divided into exposure domains based on their typical usage. The underground mine comprises subsystems including new constructions (excavations) at various stages of the development or production cycles, established travelways and infrastructure areas, ongoing maintenance and rehabilitation of long-term excavations as well as inactive, perhaps unmaintained, areas. Each of these excavation categories will have typical tasks associated with it, varying from haulage traffic, to service activities, to ground support installation. Their mixture and timing will combine to give an overall exposure for the particular excavation over the period of interest, e.g. over a shift. Figure 1 is a conceptual flowchart showing this methodology.

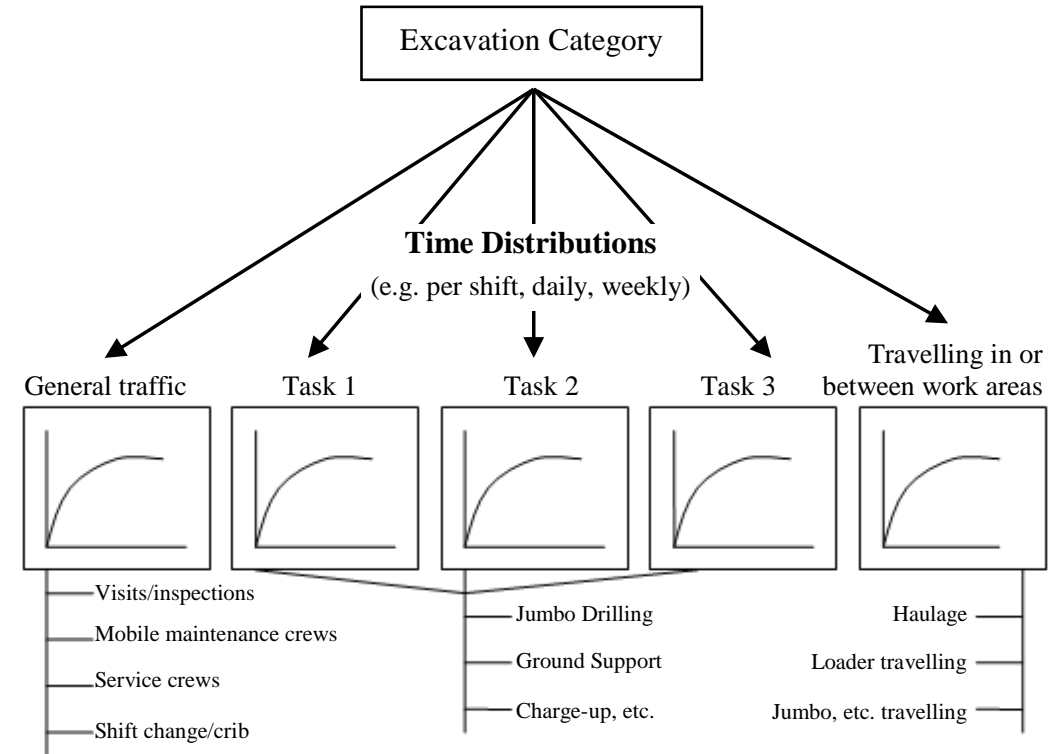

Figure 1 Flowchart of tasks contributing to exposure in a mine excavation 
Several key findings from Potvin et al. (2001) were of relevance to the exposure research and the following conclusions were drawn:

- The area close to the active face of drives is recognised as a particularly hazardous location, common to many mines. This includes the unsupported ground (face and/or backs) within a few metres of the face as well as supported ground slightly further away.

- With the development cycle creating almost continuous exposure of personnel at active faces, the combination of high exposure and hazard create a very high risk workplace, as reflected in the injury statistics. Therefore, the time spent by personnel in particular locations is of significance for the exposure model.

- The large proportion of injuries caused by small to moderate sized rockfalls $(<1 \mathrm{t})$ indicates that the exposure model should account for personnel vulnerability to these conditions as well as to the large falls of ground. These small rockfalls would be of minor significance to most heavy vehicles, and personnel inside, but have severe consequences for personnel outside vehicles.

Through a literature review and the analysis of underground mining rockfall databases and accident records, the exposure model parameters were identified. In developing a procedure for quantifying the exposure of underground personnel and equipment to geotechnical hazards, three components were considered critical:

- The vulnerability of the personnel/asset should a fall of ground occur (their relative level of protection), represented by factor E1.

- The proximity of the worker/equipment to the geotechnical hazard (E2).

- The amount of time exposed, incorporating the number of personnel $(\mathrm{N})$, typical task time $(\Delta \mathrm{t})$ and the proportion of this time spent in any particularly hazardous duties.

\subsection{Vulnerability to geotechnical hazards}

In quantifying the exposure of personnel, a key factor is the level of protection the worker has should a rockfall/rockburst occur. Obviously someone working outside their vehicle with the standard personnel protective equipment, i.e. hard hat, is more vulnerable than when they are inside a cab with a rollover protective structure (ROPS) or falling object protective structure (FOPS). Conversely, the cab of a machine working in a heading provides a much larger target for a vertical impact than simply an isolated personnel. The result of combining (multiplying) these two opposing factors to give an overall personnel vulnerability rating (E1) is shown in the following table.

\section{Table 1 Personnel vulnerability ratings}

\begin{tabular}{ll}
\hline Protection Type & E1 \\
\hline Enclosed ROPS/FOPS* cab & 0.8 \\
ROPS/FOPS open cab & 1 \\
FOPS canopy & 2 \\
Unreinforced cab & 20 \\
Personal protective equipment & 50 \\
\cline { 2 - 2 } Note*: This designation of ROPS/FOPS means that the machine has both a rollover structure and a protective canopy
\end{tabular}

These values determined for E1 were based upon the impact energy ratings for FOPS (AS 2294.3, 1997), ROPS (AS 2294.2, 1997) and hard hats/helmets (AS 1801, 1997) in the Australian Standard testing procedures.

\subsection{Hazard proximity and uncertainty}

Other complexities taken into account in the model are the proximity of the operator and equipment to known geotechnical hazards (E2) and a measure of the uncertainty associated with the hazard assessment $(\% \mathrm{HT})$. Areas identified as hazardous would typically include active development faces, brows of stopes, 
priority areas for scaling and rehabilitation, displacing faults and shears, areas of water ingress, backs that are unsupported or have no surface support and locations of seismic activity. Those associated with greater uncertainty of the hazard could be where ground conditions are changing rapidly, e.g. seismic hotspots, or where site inspections are not current, e.g. disused mine areas.

Current versions of the Australian Centre for Geomechanics (ACG) mine seismicity software MS-RAP use "minodes" spaced along excavations to record and visualise location-specific information such as the condition of the rock mass, ground support and level of seismic hazard (Heal et al., 2006). Such a site specific database removes the need for the proximity and uncertainty exposure parameters as their effect on risk is encapsulated by the rockburst potential values at each minode. Both exposure model variations are summarised in this section.

Table 2 shows the proximity rating E2 given to the various ranges of distance from the hazardous ground. These values were developed by extrapolation from injury and fatality records in the Australian rockfall database (2001) research (Potvin et al., 2001), and calibrated using Australian underground mine fatality data between 1993 and 2001. The relative numbers of injuries recorded within varying distances of the face of active headings provided the basis for the $\mathrm{E} 2$ values.

\section{Table 2 Proximity level factor}

\begin{tabular}{cc}
\hline Proximity to Hazard & E2 \\
\hline$<5 \mathrm{~m}$ & 10 \\
$5-15 \mathrm{~m}$ & 5 \\
$15-30 \mathrm{~m}$ & 2 \\
$>30 \mathrm{~m}$ & 1 \\
\hline
\end{tabular}

Ideally, the level of confidence in the ground hazard assessment would be quantified as part of the hazard analysis, but practically the model had to allow for when this was not the case. Of particular interest were activities (Table 3) such as manual scaling, inspecting unstable ground, working close to an unsupported face and entering old, unmaintained mining areas. In these cases, the geotechnical hazards may not be well identified or understood because of rapidly changing or variable ground conditions. It is reasoned that the vulnerability (hence, exposure) increases as knowledge of the hazards decreases. Therefore the relative proportion of time spent by the worker in performing such work has been estimated and incorporated in the exposure profile as an additional component termed the ground hazard uncertainty parameter and designated hazardous time proportion (\%HT).

A corollary to this methodology is that when measures such as geotechnical investigations are carried out, the uncertainty may be reduced and associated tasks therefore fall into the known geotechnical hazards group, with a consequent reduction in the exposure rating and also risk. This can be directly applied to the case of re-entry following a blast, where the first personnel through have the highest exposure, but after inspection/scaling the uncertainty and thus exposure, decreases.

Table 3 Selected activities with higher ground hazard uncertainty

\begin{tabular}{l}
\hline Activities with Higher Uncertainty of Ground Hazard \\
\hline Re-entry following stope firing \\
Inspecting unstable ground/hang-ups, etc. \\
Installation of ground support/rehabilitation \\
Manual scaling \\
Working at unsupported face/brow \\
Working near backs/pillars without surface support \\
Entering old, unmaintained mining areas
\end{tabular}




\subsection{Hourly exposure rating}

The three components E1, E2 and \%HT can be combined to determine an hourly exposure rating (E/hr) as follows:

- Determine the vulnerability of the personnel or asset (= factor E1).

- Average the proximity of the activity to known geotechnical hazards (= factor E2).

- For general activities, multiply these two factors to give $\mathrm{E} / \mathrm{hr}=\mathrm{E} 1 \times \mathrm{E} 2$.

- For areas/tasks where greater uncertainty is involved in the geotechnical hazard assessment, add a high risk task component using the proportion of total activity time taken for this task (\%HT) and the worst case proximity factor $(\mathrm{E} 2=10)$.

- So overall, $\mathrm{E} / \mathrm{hr}=\mathrm{E} 1 \times \mathrm{E} 2+(\% \mathrm{HT} \times \mathrm{E} 1 \times 10)$.

\subsection{Exposure time}

In the mine sites studied by Owen (2004) there have been records available on the typical timing of major tasks and activities, usually sourced from the mine planning departments. These task times had some variation, particularly for production tasks when the stope sizes differ significantly. However, when calculated on a per shift basis, most of these task times compared well across different time periods. They were also reasonably consistent across different mines as long as similar equipment and work practices had been used.

Both to provide a basis for comparison across mine sites, and for cases where records are not available, such as for a new mine, time distributions of the major mining tasks were calculated. To quantify the exposure time for both underground workers and equipment, information was collected from several weeks of records from the mine production management system PITRAM, at two different Australian underground mines. These were BHP Billiton's Cannington silver/lead/zinc mine and WMC's Leinster Nickel Operation (now BHP Billiton Nickel West) Perseverance Mine. From this data, time distributions were developed for major tasks (jumbo drilling, mucking, charge-up, etc.) for each active excavation type such as development headings or stopes.

It is suggested that, rather than adopting the average or median $(50 \%)$ value, the time used for the most critical mine tasks should conservatively be the time from the cumulative distribution (cdf) chart corresponding to the $80 \%$ range; this more conservative estimate of task time is referred to herein as T80. In other words, in $80 \%$ of cases, the task takes no more than time T80 for completion. The validity of adopting the median or T80 times will depend on the site specific operating conditions and analysis objectives, as well as the shape of the time distribution curve.

An example of a probability density function (pdf) and cdf for the development charging task time can be seen in Figure 2. 


\section{Development Charge-Up}

LogLogistic $[-1.71,321,5.8)$

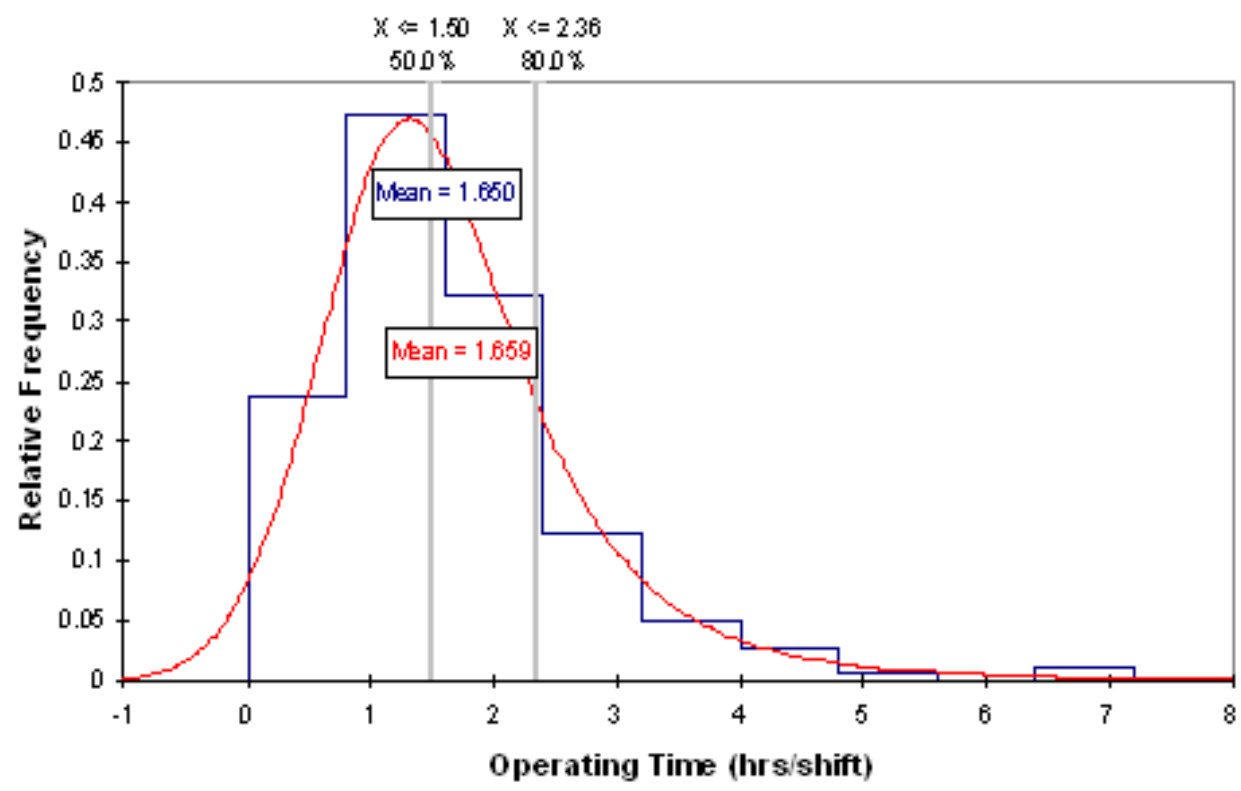

(a)

\section{D evelopment Charge-Up}

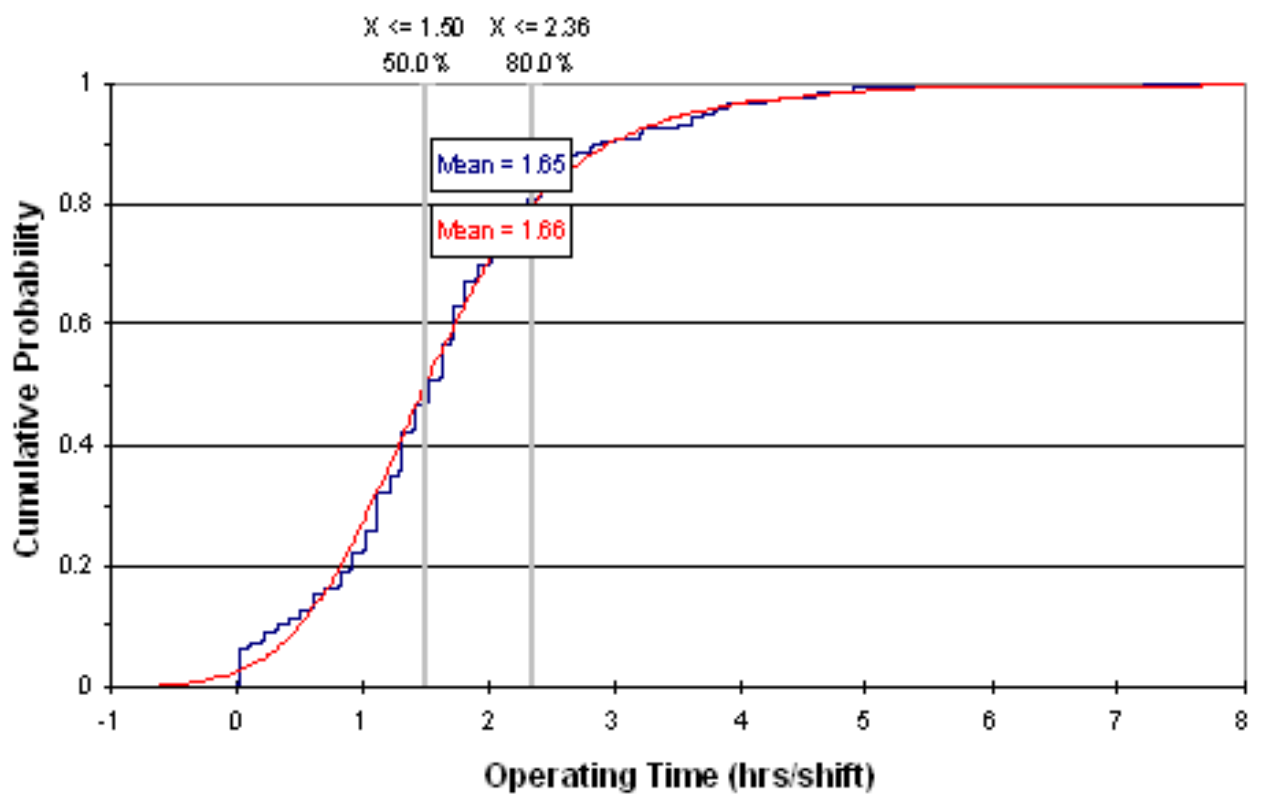

(b)

Figure 2 Time distribution for development charge-up: (a) pdf; and (b) cdf

\section{Exposure profiles}

Table 4 lists the workforce exposure profiles suggested for different excavation categories. 
Table 4 Exposure profiles applicable to various excavation categories

\begin{tabular}{|c|c|c|}
\hline $\begin{array}{l}\text { Excavation } \\
\text { Area }\end{array}$ & Excavation Category & $\begin{array}{l}\text { Calculation Method for Maximum } \\
\text { Exposure per Shift }\end{array}$ \\
\hline 1 & Decline (established levels) & Mine traffic + tramming \\
\hline 2 & Shaft & $\begin{array}{l}\text { Total underground workforce at start } \\
\text { of shift }\end{array}$ \\
\hline 3 & Infrastructure area & Local workforce profile \\
\hline 4 & Inactive levels - accesses and drives & Mobile crew profile \\
\hline 5 & Development area - near working face & Development cycle profile \\
\hline 6 & Development area — accesses/drives & Development cycle tramming + traffic \\
\hline 7 & $\begin{array}{l}\text { Production level }- \text { drilling horizon }- \\
\text { near working face }\end{array}$ & Production drilling cycle profile \\
\hline 8 & $\begin{array}{l}\text { Production level }- \text { drilling horizon }- \\
\text { accesses/drives }\end{array}$ & $\begin{array}{l}\text { Production drilling cycle tramming }+ \\
\text { traffic }\end{array}$ \\
\hline 9 & $\begin{array}{l}\text { Production level — mucking horizon - } \\
\text { near working face }\end{array}$ & Production mucking cycle \\
\hline 10 & $\begin{array}{l}\text { Production level - mucking horizon - } \\
\text { accesses/drives }\end{array}$ & $\begin{array}{l}\text { Production mucking cycle tramming }+ \\
\text { traffic }\end{array}$ \\
\hline 11 & Designated no entry area & Negligible exposure \\
\hline 12 & $\begin{array}{l}\text { Designated no unauthorised } \\
\text { entry/limited access area }\end{array}$ & Limited inspections only \\
\hline
\end{tabular}

The following sections detail how to determine the exposure profiles for typical development and production cycles.

\subsection{Exposure profiles for development and production cycles}

The end result of the profiling is a value representing the typical maximum exposure rating per shift for an active development heading or production area. The steps involved are:

- List the activities in the development or production cycle, e.g. for a development heading: fire face, muck heading, install ground support, bore face, etc.

- Include regular associated activities such as survey, geotechnical inspections, geologist sampling, repairs and shift boss inspections.

- For each of these activities list the number of personnel involved in each task $(\mathrm{N})$ and their typical time spent in the excavation area performing the task $(\Delta \mathrm{t})$. The product of these two $(\mathrm{N} \Delta \mathrm{t})$ gives the man hours associated with that task.

- For each activity calculate the $\mathrm{E} / \mathrm{hr}$ as described earlier.

- The exposure rating (E) for each activity is then simply:

$$
E_{\text {activity/shift }}=\mathrm{N} \Delta \mathrm{t} . \mathrm{E} / \mathrm{hr}
$$

- Select all activities that are possible to accomplish within one shift and sum their E. This value is the maximum $\mathrm{E}$ per shift for the development heading or production area and is referred to as $\mathrm{E}_{\max }$ for the particular excavation category.

$$
\mathrm{E}_{\max }=\mathrm{E}_{\text {max.location/shift }}=\Sigma_{\text {shift }}(\mathrm{N} \Delta \mathrm{t} . \mathrm{E} / \mathrm{hr})
$$


Examples follow of the calculation of personnel exposure ratings for three major mining tasks: production mucking (bogging), development jumbo boring, and charging a face. Figure 3 shows the mapping of the exposure ratings across a mine level.

\subsubsection{Example 1-low personnel exposure}

Loader mucking near stope:

$\mathrm{ROPS} \mathrm{cab} \rightarrow \mathrm{E} 1=1$

Machine working within $5 \mathrm{~m}$ of brow $\rightarrow \mathrm{E} 2=10$

Good, supported ground, operator stays in machine $\rightarrow \% \mathrm{HT}=0$

$\mathrm{E} / \mathrm{hr}=\mathrm{E} 1 \times \mathrm{E} 2+\% \mathrm{HT} \times \mathrm{E} 1 \times 10=1 \times 10+0 \times 0.8 \times 10=10$

From the generic time distribution chart for a production loader (Owen, 2004):

$\mathrm{T} 80=6.7 \mathrm{hrs} / \mathrm{shift}$ so using task time $\Delta \mathrm{t}=\mathrm{T} 80$, and one operator

$\mathrm{N} \Delta \mathrm{t}=1 \times 6.7=6.7 \mathrm{man}$ hours $/ \mathrm{shift}$

So the production mucking E:

$\mathrm{E}_{\text {activity/shift }}=\mathrm{E} / \mathrm{hr} \times \mathrm{N} \Delta \mathrm{t}=10 \times 6.7=67$

\subsubsection{Example 2-moderate personnel exposure}

Development jumbo operator boring a face:

Operator under a FOPS canopy $\rightarrow \mathrm{E} 1=2$

When in cab, operator is $5-10 \mathrm{~m}$ from face $\rightarrow \mathrm{E} 2=5$

From surveys, approximately $20 \%$ of time is spent outside the jumbo and closer to the face, e.g. changing drill rods $\rightarrow \% \mathrm{HT}=20 \%, \mathrm{E} 1=50$

$\mathrm{E} / \mathrm{hr}=\mathrm{E} 1 \times \mathrm{E} 2+\% \mathrm{HT} \times \mathrm{E} 1 \times 10=2 \times 5+20 \% \times 50 \times 10=110 \sim 100$

From the generic time distribution chart (Owen, 2004), T80 $=3.4 \mathrm{hrs} / \mathrm{shift}$

Using task time $\Delta \mathrm{t}=\mathrm{T} 80$, and assuming one operator (no offsider) so $\mathrm{N}=1$

So the development drill nodal E:

$\mathrm{E}_{\text {activity/shift }}=\mathrm{E} / \mathrm{hr} \times \mathrm{N} \Delta \mathrm{t}=100 \times 3.4=340$

\subsubsection{Example 3 - high personnel exposure}

Development charge-up crew loading a development face:

Personnel protected only with $\mathrm{PPE} \rightarrow \mathrm{E} 1=50$

Working within $5 \mathrm{~m}$ of face $\rightarrow \mathrm{E} 2=10$

Personnel working in direct contact with unsupported face and beyond last row of bolts in the back $\rightarrow \% \mathrm{HT}=100 \%$

$\mathrm{E} / \mathrm{hr}=\mathrm{E} 1 \times \mathrm{E} 2+\% \mathrm{HT} \times \mathrm{E} 1 \times 10=50 \times 10+100 \% \times 50 \times 10=1000$

From the generic time distribution chart for charge-up (Owen, 2004) T80 $=2.36 \mathrm{hrs} / \mathrm{shift}$. Using task time $\Delta \mathrm{t}=\mathrm{T} 80$, and assuming two operators charging the face:

$\mathrm{N} \Delta \mathrm{t}=2 \times 2.36=4.7$ man hours/shift

Development charge nodal E:

$\mathrm{E}_{\text {activity/shift }}=\mathrm{E} / \mathrm{hr} \times \mathrm{N} \Delta \mathrm{t}=1000 \times 4.7=4700$ 


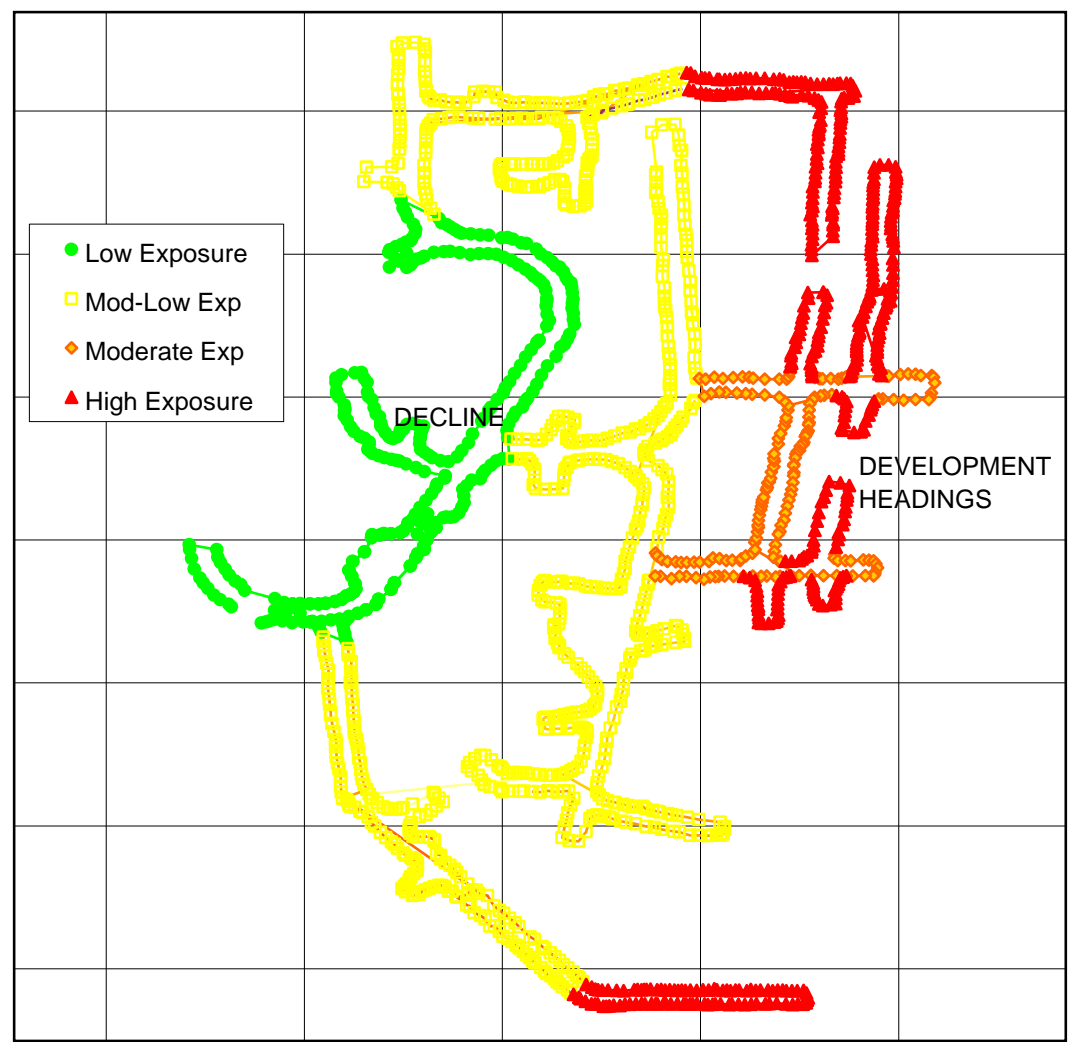

Figure 3 Exposure map of an active development level in a Western Australian underground mine

\section{Converting exposure ratings to probabilities of fatal injury}

The E incorporates both the likelihood of exposure and a measure of the likelihood of injury. The exposure profiles and time component (in man hours) can be used to estimate the probability that, given a rockfall/rockburst at the specified location, personnel or vehicle will be impacted. To calibrate the exposure rating in the travelways with some temporal probability of a rock falling onto a moving vehicle and resulting in injury, methods using geometric probability density functions from landslide risk management guidelines (AGS, 2000; Bunce et al., 1997) were adopted. From AGS (2000) the probability (P) of a vehicle being hit by a rockfall is:

$\mathrm{P}$

$$
\begin{aligned}
& =1-\left(1-\mathrm{P}_{\mathrm{sh}}\right)^{\mathrm{Nr}} \\
& =1-\left[1-\left(\mathrm{N}_{\mathrm{v}} / 24\right) \cdot(\mathrm{L} / 1000) / \mathrm{V}_{\mathrm{v}}\right]^{\mathrm{Nr}}
\end{aligned}
$$

where:

$$
\begin{array}{ll}
\mathrm{N}_{\mathrm{r}} & \text { = number of rockfalls per day. } \\
\mathrm{N}_{\mathrm{v}} & \text { = number of vehicles passing by each day. } \\
\mathrm{L} & \text { = vehicle length }(\mathrm{m}) . \\
\mathrm{V}_{\mathrm{v}} & \text { = velocity of vehicle }(\mathrm{km} / \mathrm{h}) .
\end{array}
$$

This temporal probability scales directly with the rockfall frequency. The choices of the appropriate numbers of rockfalls per day to use in the temporal probability calculations were based on data extracted from the previously referenced ACG Australian rockfall database (2001). The database recorded that $89 \%$ of the rockfalls occurred within $50 \mathrm{~m}$ of the active face, e.g. development face or stope brow. This equated to an average across the mines of about five rockfalls/year/mine, and eight rockfalls/year for the larger mines. Reported rockfalls that occurred greater than $50 \mathrm{~m}$ away from the face therefore represented $11 \%$ of the total records, which equated to an approximate rockfall frequency of $1.8-2.5$ rockfalls/year across declines, general access drives and intersections within a typical mine. 
Using these numbers, sample calculations of the probability of impact (following the methodology in the landslide guidelines) are provided for declines and development headings.

\subsection{Example 1 - decline}

For a particular section of roadway, say a decline, let:

$$
\begin{array}{ll}
\mathrm{N}_{\mathrm{r}} & =\text { number of rockfalls per day for decline }=1 \text { per year }(\text { say })=1 / 365 \text { per day } \\
\mathrm{N}_{\mathrm{v}} & \quad=\text { number of vehicles passing by each day }=2 \times \text { average number of trips per shift }=400 \\
\mathrm{~L} & =\text { vehicle length }(\mathrm{m})=6 \mathrm{~m} \text { approximated average } \\
\mathrm{V}_{\mathrm{v}} & =\text { velocity of vehicle }(\mathrm{km} / \mathrm{h})=15 \mathrm{~km} / \mathrm{h} \\
\mathrm{P}_{\mathrm{sh}} & =\text { probability of vehicle being on the section of road where the rock falls } \\
& =\left(\mathrm{N}_{\mathrm{v}} / 24\right) .(\mathrm{L} / 1000) / \mathrm{V}_{\mathrm{v}} \\
& =(400 / 24) .(6 / 1000) / 15=1 / 150 \\
\mathrm{P} & =\text { daily probability of vehicle being hit by a rockfall } \\
& =1-\left(1-\mathrm{P}_{\mathrm{sh}}\right)^{\mathrm{Nr}}=1-(1-1 / 150)(1 / 365)=0.0000183=1 \text { in } 55,000 \text { or } 1 \text { in } 150 \text { over a year }
\end{array}
$$

An annual probability of 1 in 150 sounds high but only represents the chances of a rockfall (of any reportable size) hitting a vehicle, not the much lower likelihood of resulting in injury or death.

The area close to an active development face has almost continuous exposure to personnel and/or vehicles, being only vacated at firing time. Therefore a vehicle travel calculation is not particularly relevant. In the exposure model, it was determined that the first $15 \mathrm{~m}$ length of drive was typically occupied by the main equipment at the face where approximately $80 \%$ of the rockfalls occurred, with an additional $15 \mathrm{~m}$ drive length potentially occupied by support vehicles. From development cycle exposure profiling, support activities such as surveys, inspections and repairs take $20-25 \%$ of the shift and were assumed to individually occupy an average 5-6 m length of drive. For the following example it was assumed that the average (small to moderate size) rockfall affects a $1 \mathrm{~m}$ length of drive.

\subsection{Example 2 - development heading}

Near the active face of a drive:

$$
\begin{array}{ll}
\mathrm{P}_{\mathrm{sh}} & =\text { probability of any vehicle being on the section of drive where the rock falls: } \\
& =1 / 50[80 \% \times 15 \times 90 \%+20 \% \times 5.5 \times 25 \%]=0.22 \\
\mathrm{~N}_{\mathrm{r}} & =\text { number of rockfalls per day for roadway }=8 \text { per year }=8 / 365 \text { per day } \\
\mathrm{P} & =\text { daily probability of vehicle being hit by a rockfall: } \\
& =1-\left(1-\mathrm{P}_{\mathrm{sh}}\right)^{\mathrm{Nr}}=1-(1-0.22)^{(8 / 365)}=0.00545=1 \text { in } 180
\end{array}
$$

For the vehicle cab:

$\mathrm{P}_{\mathrm{sh}} \quad=$ probability of either a heavy vehicle (HV) or light vehicle (LV) cab being in the drive where the rock falls:

$=1 / 50[80 \% \times 1 \times 90 \%+20 \% \times 1 \times 25 \%]=0.0154$

$\mathrm{P} \quad=$ daily probability of vehicle cab being hit by a rockfall:

$$
=1-\left(1-\mathrm{P}_{\mathrm{sh}}\right)^{\mathrm{Nr}}=1-(1-0.0154)^{(8 / 365)}=0.00034=1 \text { in } 3000
$$

Probability of personnel being inside a vehicle when rockfall occurs using Owen (2004) survey data:

$$
\begin{aligned}
& =55 \%(\text { development mining vehicles near face }) \\
& =15 \%(\text { support vehicles })
\end{aligned}
$$


So,

$\mathrm{P}_{\mathrm{sh}} \quad=$ probability of personnel being outside a vehicle where the rock falls:

$=1 / 50[45 \% \times 80 \% \times 1 \times 90 \%+85 \% \times 20 \% \times 1 \times 25 \%]=0.0073$

$\mathrm{N}_{\mathrm{r}} \quad=$ number of rockfalls per day for heading $=8$ per year $=8 / 365$ per day

$\mathrm{P} \quad$ = daily probability of personnel being hit by a rockfall:

$=1-\left(1-\mathrm{P}_{\mathrm{sh}}\right)^{\mathrm{Nr}}=1-(1-0.007)^{(8 / 365)}=0.00016=1$ in 6000 , i.e. about nine times more likely than a rockfall hitting a vehicle on a decline

Using the upper limit of the range of estimated probabilities of fatal injury given rockfall impact from the AGS (2000) landslide guidelines:

- Probability of fatal injury $\left(\mathrm{P}_{\mathrm{f}}\right)$ for personnel in open space struck by a rockfall $=0.7$

- For personnel in a standard light vehicle struck by a rockfall $P_{f}=0.3$

Note that the ratio of the two values of 0.3 and 0.7 is also consistent with the corresponding exposure model vulnerability parameter values of $\mathrm{E} 1=20(\mathrm{LV})$ compared to $\mathrm{E} 1=50$ (personnel). Similarly scaling between LV and mining vehicles using their respective E1 values, the probability of fatal injury for personnel in a heavy mining vehicle struck by a rockfall can be approximated as $0.075 \times 0.3=0.0225$.

The daily probability of fatal injury is then calculated from a summation of the products of the daily probability of impact and probability of fatal injury given impact for the three alternatives of personnel being outside a vehicle, inside a HV or inside a LV.

For the development heading described previously:

$$
\begin{aligned}
\mathrm{P}_{\mathrm{f}} \quad & 1 / 3150 \times 55 \% \times 0.0225+1 / 45,600 \times 15 \% \times 0.3+1 / 6000 \times 0.7 \\
= & 1 / 255,000+1 / 1,013,000+1 / 8500 \\
= & 0.0001216 \text { or approximately } 1 \text { in } 8200 \text { on any given day. Or an annual probability of } 1 \text { in } \\
& 16 \text { across all development headings over the year. }
\end{aligned}
$$

Exposure profiles were similarly determined for declines and other travelways, resulting in the following estimate of the annual risk of fatality due to rockfalls in a typical mine's travelways:

$$
\mathrm{Pf}=1 / 124,000 \times 0.3 \times 365=0.0009 \text {, or } 1 \text { in } 1100
$$

There were 26 mines in the updated Australian rockfall database (2001) so by combining the fatality probabilities for headings and travelways, the total annual probability of fatal injury in the Australian underground metalliferous mines represented by the database can be estimated by:

Annual Australian underground mine $\mathrm{P}_{\mathrm{f}}=26 \times(1 / 16+1 / 1100)=1.2$

Therefore, one would expect, on average, one to two fatalities per year due to rockfalls in underground metalliferous mines across Australia. This value is consistent with the statistics recorded by the Australian rockfall database (2001). It is also consistent with the most recent Australia annual safety reports from the Minerals Council of Australia (2007) documenting fatalities due to rockfalls in underground metalliferous mines. There were two fatalities in this sector during the 2005-2006 reporting period (one in Western Australia and one in Tasmania), and one (Western Australian) fatality in the 2006-2007 year.

\section{Conclusions}

The methodology presented has shown the profiling of workforce exposure and how to quantify the exposure of underground personnel to geotechnical hazards. The exposure model parameters were developed using both empirical data and mechanistic principles. Examples of the application of this model to key activities in underground mines were shown and a full listing is given in Table 5.

Further detailed case studies in Owen (2004) provide typical exposure ratings calculated for the various drives, development and production headings based on the mining activities and traffic profiles determined from shift records and survey data. These ratings were used in the risk matrix shown in Table 6. Also 
introduced was a method to combine the exposure model with rockfall/rockburst frequencies to calculate probabilities of impact and potential injury to personnel working or travelling underground. The results can be represented by a risk matrix such as Table 6, developed from Owen (2004) and Heal et al. (2006).

Table 5 Typical hourly exposure parameters for mine activities (Owen, 2004)

\begin{tabular}{|c|c|c|c|c|}
\hline Activity & E1 & $\mathbf{E 2}$ & $\% \mathrm{HT}$ & E/hr \\
\hline Bog/muck development & 1 & 10 & $0-5 \%$ & $10-35$ \\
\hline Bore development face & 2 & 5 & $20 \%$ & 110 \\
\hline Charge development face & 50 & 10 & $100 \%$ & 1000 \\
\hline Charge rings & 50 & 5 & $0-25 \%$ & $250-370$ \\
\hline Diamond drilling & 50 & 1 & $0 \%$ & 50 \\
\hline Drilling for primary ground support & 2 & 5 & $50 \%$ & 260 \\
\hline Drilling for secondary support & 2 & 5 & $5 \%$ & 35 \\
\hline Geotech inspection/sampling & 50 & 5 & $20 \%$ & 350 \\
\hline Inspections/mapping & 50 & 5 & $0-20 \%$ & $250-350$ \\
\hline Installing primary ground reinforcement/support (no FOPS) & 50 & 10 & $50 \%$ & 750 \\
\hline Installing primary ground reinforcement/support (with FOPS) & 2 & 10 & $20 \%$ & 120 \\
\hline Installation of secondary ground reinforcement/support (no FOPS) & 50 & 10 & $5 \%$ & 525 \\
\hline Installation of secondary ground reinforcement/support (with FOPS) & 2 & 5 & $20 \%$ & 110 \\
\hline Manual scaling & 50 & 10 & $100 \%$ & 1000 \\
\hline Mechanical scaling (with FOPS) & 2 & 10 & $20 \%$ & 120 \\
\hline Production drilling & 2 & 5 & $5 \%$ & 35 \\
\hline Production mucking - conventional & 1 & 5 & $0-5 \%$ & $5-30$ \\
\hline Production mucking — remote & 50 & 2 & $0 \%$ & 100 \\
\hline Re-install services & 50 & 5 & $5 \%$ & 275 \\
\hline Repairs in heading & 50 & $2-5$ & $5 \%$ & $125-200$ \\
\hline Repairs in workshop & 50 & 1 & $0 \%$ & 50 \\
\hline Ring preparation and clean out & 50 & 5 & $20 \%$ & 350 \\
\hline Services & 50 & 1 & $0 \%$ & 50 \\
\hline Shotcreting/fibrecreting & 50 & 5 & $10 \%$ & 300 \\
\hline Surveying & 50 & 2 & $5 \%$ & 125 \\
\hline Travelling & 20 & 1 & $0 \%$ & 20 \\
\hline Water down/check area & 50 & 5 & $10 \%$ & 300 \\
\hline
\end{tabular}


Table 6 Risk matrix for rockfalls/rockbursts (Owen, 2004; Heal et al., 2006)

\begin{tabular}{|c|c|c|c|c|c|c|c|c|}
\hline \multirow[b]{2}{*}{ Excavation Category } & \multirow[b]{2}{*}{$\begin{array}{c}\text { Exposure } \\
\text { Rating } \\
\text { E/shift }\end{array}$} & \multicolumn{7}{|c|}{ Probability of Large Rockfall (>10 t) } \\
\hline & & $<0.05$ & $\begin{array}{c}0.05- \\
0.10\end{array}$ & $\begin{array}{c}0.10- \\
0.25\end{array}$ & $\begin{array}{c}0.25- \\
0.50\end{array}$ & $\begin{array}{c}0.50- \\
0.75\end{array}$ & $\begin{array}{c}0.75- \\
0.90\end{array}$ & $>0.90$ \\
\hline $\begin{array}{l}\text { Restricted access } \\
\text { (no entry) }\end{array}$ & 100 & VL & VL & $\mathrm{L}$ & M & M & $\mathrm{H}$ & $\mathrm{H}$ \\
\hline Decline & 1000 & VL & $\mathrm{L}$ & M & M & $\mathrm{H}$ & VH & VH \\
\hline $\begin{array}{l}\text { Travel way - no active } \\
\text { mining }\end{array}$ & 1000 & VL & $\mathrm{L}$ & M & M & $\mathrm{H}$ & VH & VH \\
\hline $\begin{array}{l}\text { Travel way - mining on } \\
\text { level }\end{array}$ & 2000 & VL & $\mathrm{L}$ & M & M & $\mathrm{H}$ & VH & VH \\
\hline Production mucking area & 3000 & VL & $\mathrm{L}$ & M & M & $\mathrm{H}$ & VH & VH \\
\hline $\begin{array}{l}\text { Busy level travel } \\
\text { way/drive }\end{array}$ & 4000 & VL & $\mathrm{L}$ & M & M & $\mathrm{H}$ & VH & VH \\
\hline Development heading & 7000 & $\mathrm{~L}$ & M & M & $\mathrm{H}$ & VH & VH & $\mathrm{E}$ \\
\hline Production drilling & 10,000 & M & $\mathrm{H}$ & $\mathrm{H}$ & $\mathrm{H}$ & VH & $\mathrm{E}$ & $\mathrm{E}$ \\
\hline Production charge-up & 10,000 & M & $\mathrm{H}$ & $\mathrm{H}$ & $\mathrm{H}$ & VH & $\mathrm{E}$ & $\mathrm{E}$ \\
\hline $\begin{array}{l}\text { Infrastructure } \\
\text { areas/workshops }\end{array}$ & 14,000 & M & $\mathrm{H}$ & VH & VH & $\mathrm{E}$ & $\mathrm{E}$ & $\mathrm{E}$ \\
\hline
\end{tabular}

Seismic Risk Levels: VL = Very Low; $\mathrm{L}=$ Low; $\mathrm{M}=$ Moderate; $\mathrm{H}=$ High $; \mathrm{VH}=$ Very High; $\mathrm{E}=$ Extreme

Table 7 Annual fatality rates used to define risk levels

\begin{tabular}{lll}
\hline \multicolumn{2}{l}{ Annual Fatality Risk } \\
\hline Very Low & $<1$ in 100,000 & Acceptable risk in civil engineering (for <10 fatalities) \\
Low & 1 in $50,000-100,000$ & \\
Moderate & 1 in $15,000-50,000$ & \\
High & 1 in $5000-15,000$ & Annual highway vehicle fatality rate $=1$ in 10,000 \\
Very High & 1 in $5000-1500$ & $\begin{array}{l}\text { Annual fatality incidence per employee in Western Australia } \\
\text { underground metalliferous mines } 1998-2008\end{array}$ \\
Extreme & $>1$ in 1500 &
\end{tabular}

\section{Acknowledgements}

The support of the following mines and organisations in providing data for analysis is gratefully acknowledged: the Australian Centre for Geomechanics, Big Bell mine, BHP Billiton's Cannington and Perseverance mines and Noranda's Brunswick mine.

\section{References}

Australian Geomechanics Society (AGS) (2000) Australian Geomechanics Society Sub-Committee on Landslide Risk Management, Landslide Risk Management, Australian Geomechanics, Vol. 35, No. 1, pp. 49-92.

Australian Rockfall Database (2001) CD rom format only, Australian Centre for Geomechanics.

Australian Standards (AS) 1801 (1997) Occupational Protective Helmets. Standards Association of Australia.

Australian Standards (AS) 2294.2 (1997) Earth-moving machinery — Protective structures. Part 2: Laboratory tests and performance requirements for roll-over protective structures. Standards Association of Australia. 
Australian Standards (AS) 2294.3 (1997) Earth-moving machinery — Protective structures. Part 3: Laboratory tests and performance requirements for falling object protective structures. Standards Association of Australia.

Bunce, C.M., Cruden, D.M. and Morgenstern, N.R. (1997) Assessment of the hazard from rock fall on a highway, Canadian Geotechnical Journal, Vol. 34, pp. 344-356.

Heal, D., Potvin, Y. and Hudyma, M.R. (2006) Evaluating Rockburst Damage Potential in Underground Mines, Golden Rocks 2006, The 41st U.S. Symposium on Rock Mechanics (USRMS), 50 Years of Rock Mechanics Landmarks and Future Challenges, Golden, Colorado, June 17-21, 2006, American Rock Mechanics Association, CD format only.

Minerals Council of Australia (2007) Safety Performance Report of the Australian Minerals Industry 2006-2007, viewed 20 February 2009, http://www.minerals.org.au.

MOSHAB (1997) Prevention of Mining Fatalities Taskforce 1997, Report on the Inquiry into Fatalities in the Western Australian Mining Industry, Western Australian Mines Occupational Safety and Health Advisory Board, December 1997, Perth, Australia.

Owen, M.L. (2004) Exposure Model - Detailed Profiling and Quantification of the Exposure of Personnel to Geotechnical Hazards in Underground Mines, PhD Thesis, University of Western Australia, 309 p.

Potvin, Y., Nedin, P., Sandy, M. and Rosengren, K. (2001) Towards the Elimination of Rockfall Fatalities in Australian Mines, MERIWA Report No. 223, Project No. M341, Australian Centre for Geomechanics, ACG:1009-01, Perth, Australia, December 2001, 54 p. 